\title{
Andrographolide blocks 50-kHz ultrasonic vocalizations, hyperlocomotion and oxidative stress in an animal model of mania
}

Citation for published version (APA):

Kanazawa, L. K. S., Radulski, D. R., Pereira, G. S., Prickaerts, J., Schwarting, R. K. W., Acco, A., \& Andreatini, R. (2021). Andrographolide blocks $50-\mathrm{kHz}$ ultrasonic vocalizations, hyperlocomotion and oxidative stress in an animal model of mania. Journal of Psychiatric Research, 139, 91-98. https://doi.org/10.1016/j.jpsychires.2021.05.042

Document status and date:

Published: 01/07/2021

DOI:

10.1016/j.jpsychires.2021.05.042

Document Version:

Publisher's PDF, also known as Version of record

Document license:

Taverne

Please check the document version of this publication:

- A submitted manuscript is the version of the article upon submission and before peer-review. There can be important differences between the submitted version and the official published version of record.

People interested in the research are advised to contact the author for the final version of the publication, or visit the DOI to the publisher's website.

- The final author version and the galley proof are versions of the publication after peer review.

- The final published version features the final layout of the paper including the volume, issue and page numbers.

Link to publication

\footnotetext{
General rights rights.

- You may freely distribute the URL identifying the publication in the public portal. please follow below link for the End User Agreement:

www.umlib.nl/taverne-license

Take down policy

If you believe that this document breaches copyright please contact us at:

repository@maastrichtuniversity.nl

providing details and we will investigate your claim.
}

Copyright and moral rights for the publications made accessible in the public portal are retained by the authors and/or other copyright owners and it is a condition of accessing publications that users recognise and abide by the legal requirements associated with these

- Users may download and print one copy of any publication from the public portal for the purpose of private study or research.

- You may not further distribute the material or use it for any profit-making activity or commercial gain

If the publication is distributed under the terms of Article $25 \mathrm{fa}$ of the Dutch Copyright Act, indicated by the "Taverne" license above, 


\title{
Andrographolide blocks 50-kHz ultrasonic vocalizations, hyperlocomotion and oxidative stress in an animal model of mania
}

\author{
Luiz K.S. Kanazawa ${ }^{\mathrm{a}}$, Débora R. Radulski ${ }^{\mathrm{b}}$, Gabriela S. Pereira ${ }^{\mathrm{b}}$, Jos Prickaerts ${ }^{\mathrm{c}}$, Rainer K. \\ W. Schwarting ${ }^{\mathrm{d}}$, Alexandra Acco ${ }^{\mathrm{b}}$, Roberto Andreatini ${ }^{\mathrm{a}, *}$ \\ ${ }^{a}$ Laboratory of Physiology and Pharmacology of the Central Nervous System, Department of Pharmacology, Federal University of Paraná, Centro Politécnico, 81540- \\ 990, Curitiba, PR, Brazil \\ b Laboratory of Pharmacology and Metabolism, Department of Pharmacology, Federal University of Paraná, Centro Politécnico, 81540-990, Curitiba, PR, Brazil \\ ${ }^{\mathrm{c}}$ Department of Psychiatry and Neuropsychiatry, School for Mental Health and Neuroscience (MHeNS), Maastricht University, Universiteitssingel 50 , 6229 ER \\ Maastricht, the Netherlands \\ ${ }^{\mathrm{d}}$ Behavioural Neuroscience, Experimental and Biological Psychology, and Center for Mind, Brain, and Behavior (CMBB), Philipps-Universität Marburg, Marburg, 35032, \\ Germany
}

\section{A R T I C L E I N F O}

\section{Keywords:}

Bipolar disorder

GSK3 $\beta$

Lisdexamfetamine

Lipid peroxidation

Oxidative stress

Ultrasonic vocalizations

\begin{abstract}
A B S T R A C T
In rats, lisdexamfetamine (LDX) induces manic-like behaviors such as hyperlocomotion and increases in appetitive $50-\mathrm{kHz}$ ultrasonic vocalizations (USV), which are prevented by antimanic drugs, such as lithium. Inhibition of glycogen synthase kinase 3 beta (GSK3 $\beta$ ) and antioxidant activity have been associated with antimanic effects. Thus, the aim of the present study was to evaluate the possible antimanic-like effects of andrographolide (ANDRO), a GSK3 $\beta$ inhibitor, on LDX-induced hyperlocomotion and 50-kHz USV increases. In addition, the effect of ANDRO was studied on LDX-induced oxidative stress. Lithium was used as positive control. Adult Wistar rats were treated with vehicle, lithium (100 mg/kg i.p., daily) or ANDRO ( $2 \mathrm{mg} / \mathrm{kg}$ i.p., 3 times a week) for 21 days. On the test day, either $10 \mathrm{mg} / \mathrm{kg}$ LDX or saline was administered i.p. and USV and locomotor activity were recorded. LDX administration increased the number of $50-\mathrm{kHz}$ calls, as well as locomotor activity. Repeated treatment with lithium or ANDRO prevented these effects of LDX on 50-kHz USV and locomotor activity. LDX increased lipid peroxidation (LPO) levels in rat striatum and both lithium and ANDRO prevented this effect. LPO levels in rat striatum were positively correlated with increases in 50-kHz USV emission as well as hyperlocomotion. In conclusion, the present results indicate that ANDRO has antimanic-like effects, which may be mediated by its antioxidant properties.
\end{abstract}

\section{Introduction}

Manic episodes of bipolar disorder consist of elevated or irritable mood with enhanced energy, psychomotor agitation, risk behavior, pressured speech and tachylalia, for example (American Psychiatry Association, 2013). The pharmacological treatments for the management of manic phases include mood stabilizers, such as lithium (an enzyme modulator) or sodium valproate, as well as antipsychotics (dopamine D2 receptor antagonist or partial agonist) and tamoxifen (Geddes and Miklowitz, 2013). However, these treatments are associated with the occurrence of several adverse effects, which negatively affect treatment adhesion (Baldessarini et al., 2019).

Oxidative stress has been associated with mania and antimanic drugs
(Li et al., 2010; Malhi et al., 2013; Saxena et al., 2017). Machado-Vieira et al. (2007) found an increase in thiobarbituric acid reactive substances (TBARS) in manic non-medicated patients, which was reduced after lithium treatment. Lv et al. (2020) observed that plasma malondialdehyde level is higher in manic patients, decreasing after 6 weeks of effective electroconvulsive therapy. Moreover, increased oxidative stress was found in different animal models of mania and treatment with lithium, valproate or antipsychotics reduced oxidative stress parameters (Frey et al., 2006; Brocardo et al., 2010; Arunagiri et al., 2014; Gazal et al., 2014; Valvassori et al., 2017, 2019; Hodes et al., 2018; Dal-Pont et al., 2019; de Souza et al., 2015; Menegas et al., 2020). Therefore, oxidative stress is an interesting target for new antimanic drugs.

Oxidative stress has been linked to the enzyme glycogen synthase

\footnotetext{
* Corresponding author.

E-mail address: randreatini@gmail.com (R. Andreatini).
} 
kinase $3 \beta$ (GSK3 $\beta$ ), which is proposed as the target of the antimanic effects of lithium (Li et al., 2010; Malhi et al., 2013; Valvassori et al., 2017; Dandekar et al., 2018; Dal-Pont et al., 2019). Furthermore, mice that overexpressed GSK3 $\beta$ showed manic-like behaviors (Prickaerts et al., 2006). In this line, it had been suggested that lithium and valproic acid prevented ouabain-induced manic-like behavior in rats through GSK3 $\beta$ inhibition (Valvassori et al., 2017). Moreover, the antimanic-like effect of GSK3 $\beta$ inhibition was associated to an antioxidant effect (Machado-Vieira et al., 2007; Dal Pont et al., 2019). Andrographolide (ANDRO) possesses anti-inflammatory, antioxidant and neuroprotective effects (Lim et al., 2012; Serrano et al., 2014; Mittal et al., 2016; Tan et al., 2016). Importantly, ANDRO also inhibits GSK3 $\beta$ (Serrano et al., 2014; Varela-Nallar et al., 2015). Thus, it can be hypothesized that ANDRO might display antimanic-like effects.

Psychostimulant administration is the animal model of mania most frequently used (Young et al., 2011; de Miranda et al., 2017). This model is based on the drug-induced increase in locomotor activity mainly (Young et al., 2011; de Miranda et al., 2017). More recently, we proposed that $50-\mathrm{kHz}$ ultrasonic vocalizations (USV), which are related to positive affect, could be an additional readout for manic-like states (Pereira et al., 2014; Wendler et al., 2016, 2019; Engelhardt et al., 2017). In this line, lisdexamfetamine (LDX), a pro-drug of amphetamine, induces increased locomotor activity and $50-\mathrm{kHz}$ USV that are prevented by lithium or valproate administration (Macêdo et al., 2013; de Souza et al., 2015; Wendler et al., 2016; Bristot et al., 2019). According to their spectrogram shapes, $50-\mathrm{kHz}$ USV can be classified into different subtypes (Costa et al., 2020; Mulvihill and Brudzynski, 2020; Wright et al., 2010) and we have applied a rather common classification into four subtypes: trill, step, mixed and flat (e.g. Pereira et al., 2014; Wöhr et al., 2015). The trill subtype has been related to positive affect, while the flat subtype is probably associated to social communication (Wöhr and Schwarting, 2013; Simola and Brudzynski, 2018). Moreover, the trill subtype is more affected by psychostimulant drugs and sensitive to antimanic drugs in animal models of mania (Pereira et al., 2014; Rippberger et al., 2015; Wöhr et al., 2015; Simola, 2018; Wendler et al., 2019).

The aim of the present study was to evaluate the possible antimaniclike effect of repeated treatment with ANDRO on LDX-induced increases in 50-kHz USV and locomotor activity of rats. In addition, the effect of ANDRO was studied on LDX-induced decreases in reduced glutathione (GSH) levels and increases in lipid peroxidation (LPO) levels in rat prefrontal cortex (PFC) and striatum. Lithium was used as a positive control.

Briefly, we found that repeated treatment with ANDRO prevented the effects of LDX on 50-kHz USV, locomotor activity, and increased lipid peroxidation (LPO) levels in rat striatum. Moreover, these LPO levels in rat striatum were positively correlated with the increases in 50$\mathrm{kHz}$ USV emission as well as with hyperlocomotion. Collectively, the present data suggest that ANDRO has an antimanic-like effect in LDXinduced manic-like behaviors.

\section{Experimental procedures}

\subsection{Animals}

Adult Wistar male rats (90 days old, weighing between 280 and 300 g), provided by the animal facility of Federal University of Parana, were socially housed (3-4 rats per cage) in polycarbonate cages $(41 \times 34 \times$ $16 \mathrm{~cm}$ ). The rats were maintained in a room with controlled temperature $\left(22 \pm 2{ }^{\circ} \mathrm{C}\right)$ and constant $12 \mathrm{~h}: 12 \mathrm{~h}$ light/dark cycle (with lights on between 7 a.m. and 7 p.m.); water and standard laboratory chow were available ad libitum. The experiments started one week after the rats arrived in our facility. All experiments were performed in accordance with the Brazilian Law for Animal Experimental Ethics and Care (11.794/October 8, 2008) and the Local Committee on the Care and Use of Laboratory Animals. The Institutional Ethics Board approved the experimental procedures (CEUA/BIO- protocol \#1109). All efforts were made in order to minimize the number of animals used and their suffering.

\subsection{Drugs and treatment protocol}

ANDRO (Sigma, São Paulo, Brazil) was administered at a dose of 2 mg/kg, intraperitoneally (i.p.) (Chan et al., 2010; Niranjan et al., 2010). ANDRO was dissolved in saline with dimethyl sulfoxide (DMSO, 2\%, $\mathrm{v} / \mathrm{v})$. The repeated treatment was performed throughout 21 days, 3 times/week (Monday, Wednesday and Friday). Lithium carbonate (Eurofarma, Itapevi, Brazil) was used as positive control at a dose of 100 $\mathrm{mg} / \mathrm{kg}$. Lithium was dissolved in saline and the $\mathrm{pH}$ was adjusted to 7.4 by adding $2 \mathrm{~N} \mathrm{HCl}$. Repeated treatment was performed throughout 21 days, once a day. LDX (Venvanse $\Re$, Shire, São Paulo, Brazil) was dissolved in saline at a dose of $10 \mathrm{mg} / \mathrm{kg}$. All drugs were administered i.p in a volume of $1 \mathrm{ml} / \mathrm{kg}$ body weight.

The animals were treated with vehicle (saline + DMSO), $100 \mathrm{mg} / \mathrm{kg}$ lithium or $2 \mathrm{mg} / \mathrm{kg}$ ANDRO for 21 days. On the test day, $10 \mathrm{mg} / \mathrm{kg}$ LDX or saline was administered (i.p.). One hour after LDX administration, the rats were placed individually in an acrylic box $(40 \times 40 \times 40 \mathrm{~cm})$ for the recording of USV calls and locomotor activity, as shown in Fig. 1.

\subsection{Screening test}

In order to control for inter-individual variability that could affect USV, the rats were tested for their levels of spontaneous USV in a polycarbonate cage with clean bedding as a screening test (Natusch and Schwarting, 2010). This test was performed on two consecutive days (5 min each) and the number of spontaneous $50-\mathrm{kHz}$ USV calls were recorded. Then, rats were distributed in a balanced way into the experimental groups (vehicle + saline, lithium + saline, ANDRO + saline, vehicle + LDX, lithium + LDX, ANDRO + LDX) according to the average number of $50-\mathrm{kHz}$ USV emitted in the two days. Lights were dimmed to 4 lux for all tests.

\subsection{Locomotor activity test}

USV calls and locomotor activity were recorded simultaneously. On the test day (day 30), $1 \mathrm{~h}$ after LDX (or saline) injection, the rats were placed individually into an acrylic box $(40 \times 40 \times 40 \mathrm{~cm})$, with fresh bedding, and observed for $20 \mathrm{~min}$. Recordings of the locomotor activity were made by a camera placed on top of the acrylic box. On the monitor screen, the box image was divided virtually into 9 equally sized squares and a blind observer counted the number of squares crossed by the rats.

\subsection{Ultrasonic vocalizations and analysis}

USV calls were recorded by an UltraSound Gate Condenser USV Protocol

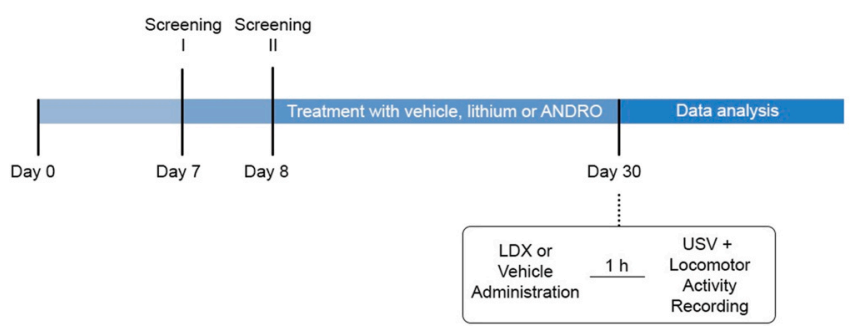

Fig. 1. Experimental protocol. ANDRO: andrographolide; LDX: lisdexamfetamine; USV: ultrasonic vocalizations recording. Screening test: individual USV recording in a clean home cage. 
Microphone (CM16; Avisoft Bioacoustics, Berlin, Germany), sensible to frequencies between 15 and $180-\mathrm{kHz}$, which was placed $45 \mathrm{~cm}$ above the acrylic box and connected to a computer with the Avisoft Recorder 2.7 software. Spectrograms from the USV recordings were generated at a frequency resolution of $488 \mathrm{~Hz}$ and a time resolution of $0.512 \mathrm{~ms}$ and were manually quantified and classified into flat, trill, step and mixed subtypes, according to previous studies (Pereira et al., 2014). USV emitted with frequencies over $33 \mathrm{kHz}$ were considered as $50-\mathrm{kHz}$ USV. The acrylic box was located in an experimental room and the Avisoft system, computer and experimenter were in an adjacent room. Data represent the sum of the USV emitted during the first 20 s period of each 1 -min interval of the 20 -min test length.

\subsection{Evaluation of oxidative stress parameters in the rat brain}

\subsubsection{Brain samples}

The rats were euthanized by decapitation immediately after the recording of USV calls and locomotor activity. The PFC and striatum were dissected, frozen in liquid nitrogen, and stored at $-80{ }^{\circ} \mathrm{C}$ until further analysis. The brain samples were homogenized in potassium phosphate buffer $(0.1 \mathrm{M}, \mathrm{pH}$ 6.5) in a 1:10 dilution. One part of the homogenate was used to determine the GSH levels, and the other was centrifuged at $9000 \times g$ in a micro-high-speed refrigerated centrifuge (NT805 Micro Centrífuga Refrigerada, Novatecnica, Piracicaba, Brazil) for 20-min. The supernatant was used to evaluate LPO.

\subsubsection{Evaluation of GSH levels}

To measure GSH levels, $100 \mu \mathrm{l}$ of the homogenate was mixed with 80 $\mu \mathrm{l}$ of $12.5 \%$ trichloroacetic acid and centrifuged at $7600 \times \mathrm{g}$ for $15 \mathrm{~min}$ at $4{ }^{\circ} \mathrm{C}$. Next, $20 \mu \mathrm{l}$ of the supernatant was mixed with $280 \mu \mathrm{l}$ of Tris buffer (0.4 M, pH 8.9) and $5 \mu \mathrm{l}$ of DTNB (5,5'-dithiobis-[2-nitrobenzoic acid]) in methanol following the protocol originally described by Sedlak and Lindsay (1968), with minor modifications. Absorbance was read at 415 nm using a multi-mode microplate reader (BioTek Synergy HT, BioTek Instruments, Highland Park, VT, USA). The individual values were interpolated in a standard curve of GSH $(0.375-3 \mu \mathrm{g})$ to corroborate the linearity of the reaction $\left(r^{2}\right.$ must be $\left.>0.99\right)$, and the values were divided by a correction factor. The results are expressed as $\mu \mathrm{g} / \mathrm{g}$ of tissue.

\subsubsection{Evaluation of LPO levels}

Lipid peroxidation was determined according to the protocol described by Jiang et al. (1992), with minor modifications. First, $100 \mu \mathrm{l}$ of the supernatant was suspended in $100 \mu \mathrm{l}$ of methanol, vortexed, and centrifuged at $5400 \times g 5 \mathrm{~min}$ at $4{ }^{\circ} \mathrm{C}$. Next, $100 \mu \mathrm{l}$ of the supernatant was added to $900 \mu \mathrm{l}$ of FOX2 reagent (Wolff's reagent; $4 \mathrm{mM} \mathrm{BHT,} 250 \mu \mathrm{M}$ $\mathrm{FeSO}_{4}, 250 \mathrm{mM} \mathrm{H}_{2} \mathrm{SO}_{4}$, and $100 \mathrm{mM}$ xylenol orange). The samples were then vortexed and incubated for $30 \mathrm{~min}$ in the dark at room temperature. Absorbance was read at $560 \mathrm{~nm}$ using a multi-mode microplate reader (BioTek Synergy HT, BioTek Instruments, Highland Park, VT, USA). The results are expressed as nmol/mg protein.

\subsubsection{Quantification of proteins}

The quantification of proteins in the PFC and striatum samples was performed according to the method designed by Bradford (1976). The reaction was examined at $595 \mathrm{~nm}$ in a microplate reader (BioTek Synergy HT, BioTek Instruments, Highland Park, VT, USA) using bovine serum albumin (BSA) as protein standard.

\subsection{Statistical analysis}

Data were analyzed by two-way ANOVA (factor LDX treatment: saline or LDX; factor repeated treatment: vehicle, lithium or ANDRO) followed by the Newman-Keuls test. Since some variables (number 50$\mathrm{kHz}$ USV and number of trill and flat subtypes) did not show homoscedasticity, the raw data were transformed in square root before statistical analysis. Differences were considered statistically significant when $\mathrm{p}<$
0.05. Pearson's correlation coefficient was used to evaluate the degree of association between variables. Data was expressed as mean \pm SD of raw data for clarity. Statistica 7.0, StatSoft (Tulsa, USA) was used for the statistical analysis.

\section{Results}

\subsection{Repeated ANDRO and lithium treatment reversed $L D X$-induced increases in $50-\mathrm{kHz}$ USV}

Two-way ANOVA of the number of USV showed effects of LDX administration $\left(\mathrm{F}_{1,37}=8.57, \mathrm{p}<0.001\right)$, repeated treatment $\left(\mathrm{F}_{2,37}=\right.$ 13.88, $\mathrm{p}<0.001$ ) and LDX administration $\mathrm{x}$ repeated treatment interaction $\left(\mathrm{F}_{2,37}=4.43, \mathrm{p}<0.05\right.$; Fig. $\left.2 \mathrm{~A}\right)$. The post hoc test indicated that LDX administration increased the number of calls $(\mathrm{p}<0.001)$. Treatment with lithium and ANDRO prevented the increases in the number of $50-\mathrm{kHz}$ calls induced by LDX ( $\mathrm{p}<0.001$ and $\mathrm{p}<0.01$, respectively). Lithium or ANDRO alone did not reduce the number of calls ( $p>0.05)$.

Call subtypes: Regarding flat calls, there was an effect of LDX administration $\left(\mathrm{F}_{1,37}=14.24, \mathrm{p}<0.001\right)$, repeated treatment $\left(\mathrm{F}_{2,37}=\right.$ 9.17, $\mathrm{p}<0.001$ ) and an interaction between LDX administration $\mathrm{x}$ repeated treatment $\left(\mathrm{F}_{2,37}=3.93, \mathrm{p}<0.05\right.$; Table 1$)$. LDX increased flat calls $(\mathrm{p}<0.001)$ and repeated lithium and ANDRO prevented this effect (both $\mathrm{p}<0.01$ ). On trill calls, there was an effect of LDX administration $\left(\mathrm{F}_{1,37}=6.36, \mathrm{p}<0.001\right)$, repeated treatment $\left(\mathrm{F}_{2,37}=11.02, \mathrm{p}<0.01\right)$ and an LDX administration $\mathrm{x}$ repeated treatment interaction $\left(\mathrm{F}_{2,37}=\right.$ 5.06, $\mathrm{p}<0.05)$. LDX increased trill calls $(\mathrm{p}<0.001)$ and repeated lithium and ANDRO prevented this effect $(\mathrm{p}<0.001$ and $<0.05$, respectively). On step calls, there was an effect of $\mathrm{LDX}$ treatment $\left(\mathrm{F}_{1,37}\right.$ $=9.29, \mathrm{p}<0.01)$, repeated treatment $\left(\mathrm{F}_{2,37}=3.27, \mathrm{p}<0.05\right)$ but not for LDX administration $x$ repeated treatment interaction $\left(F_{2,37}=2.89\right.$, NS). LDX increased step calls ( $p<0.01$; saline $=4 \pm 6$ and LDX $=12 \pm 12$, mean $\pm S D ; n=22$ and 21 , respectively) independently from repeated treatment (Table 1).

\subsection{Repeated ANDRO and lithium treatment prevented LDX-induced hyperlocomotion}

There were effects of LDX administration $\left(\mathrm{F}_{2,37}=19.81, \mathrm{p}<0.001\right)$, repeated treatment $\left(\mathrm{F}_{1,37}=9.36, \mathrm{p}<0.001\right)$ and $\mathrm{LDX}$ administration $\mathrm{x}$ repeated treatment interaction $\left(\mathrm{F}_{2,37}=4.08, \mathrm{p}<0.05\right)$. LDX administration increased locomotor activity ( $p<0.001$; Fig. $2 \mathrm{~B})$, and treatment with lithium and ANDRO prevented such hyperlocomotion $(\mathrm{p}<0.001$ and $\mathrm{p}<0.01$, respectively). Lithium or ANDRO alone did not reduce locomotor activity (both $\mathrm{p}>0.05$ ).

\subsection{Repeated ANDRO administration prevented LDX-induced lipid peroxidation in rat striatum}

\subsubsection{Lipid peroxidation}

In the striatum, two-way ANOVA showed effects of repeated treatment $\left(\mathrm{F}_{2,37}=6.34, \mathrm{p}<0.01\right), \mathrm{LDX}$ administration $\left(\mathrm{F}_{1,37}=71.53, \mathrm{p}<\right.$ $0.001)$ and LDX administration $x$ repeated treatment interaction $\left(\mathrm{F}_{2,37}\right.$ $=13.95, \mathrm{p}<0.001)$ in LPO levels. The Newman-Keuls test indicated that LDX administration increased LPO levels $(\mathrm{p}<0.001)$ and lithium and ANDRO repeated treatment prevented LDX-induced increases in LPO levels ( $\mathrm{p}<0.001$ and $\mathrm{p}<0.05$, respectively; Fig. 3A).

In the PFC, two-way ANOVA indicated that there were no effects of repeated treatment $\left(F_{2,37}=2.39, \mathrm{NS}\right)$, $\mathrm{LDX}$ administration $\left(\mathrm{F}_{1,37}=0.22\right.$, NS) or LDX administration $\mathrm{x}$ repeated treatment interaction $\left(\mathrm{F}_{2,37}=\right.$ $1.09, \mathrm{NS}$ ) in the levels of LPO (Fig. 3B).

\subsection{2. $G S H$}

In the striatum, two-way ANOVA did not indicate effects of repeated treatment $\left(\mathrm{F}_{1,37}=0.06, \mathrm{NS}\right)$, LDX administration $\left(\mathrm{F}_{1,37}=0.02\right.$, NS) or LDX administration $x$ repeated treatment interaction $\left(\mathrm{F}_{1,37}=0.02\right.$, NS) 
A

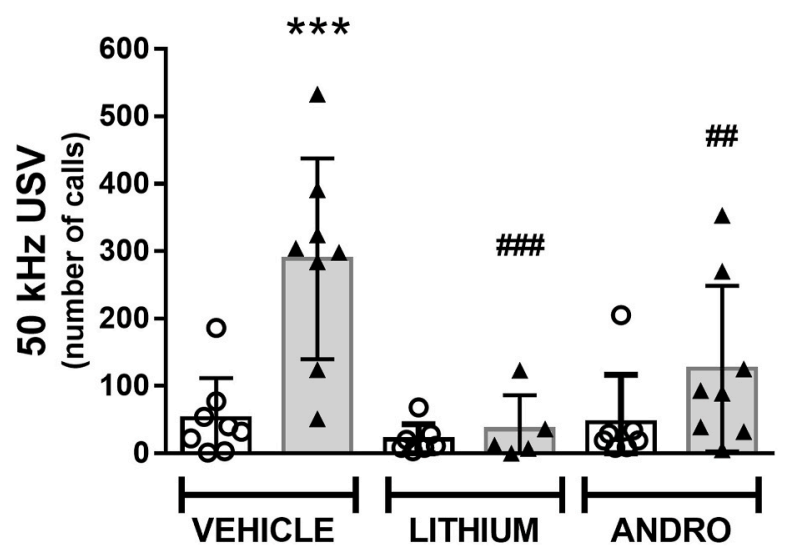

B

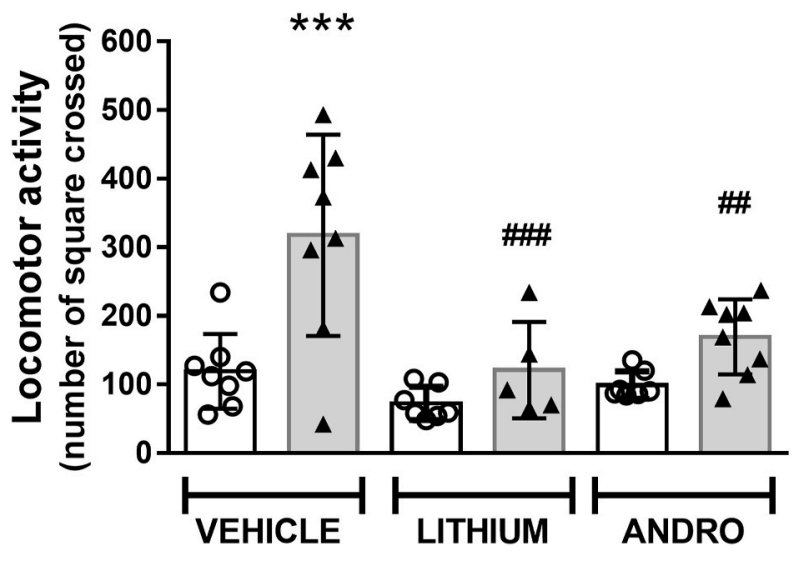

Table 1

Effects of repeated Lithium and Andrographolide (ANDRO) on acute effects of lisdexamfetamine on the number of call subtypes of $50-\mathrm{kHz}$ ultrasonic vocalizations.

\begin{tabular}{llllllll}
\hline & \multicolumn{2}{l}{ Saline } & & & \multicolumn{2}{l}{ Lisdexamfetamine } \\
\cline { 2 - 3 } & Vehicle & Lithium & ANDRO & & Vehicle & Lithium & ANDRO \\
\hline Call subtypes & & & & & & & \\
Flat & $40 \pm 45$ & $13 \pm 13$ & $28 \pm 38$ & & $204 \pm 110^{\mathrm{a}}$ & $26 \pm 38$ & $84 \pm 89$ \\
Trill & $6 \pm 10$ & $4 \pm 5$ & $10 \pm 14$ & & $49 \pm 32^{\mathrm{a}}$ & $3 \pm 5$ & $22 \pm 22$ \\
Step & $4 \pm 4$ & $3 \pm 5$ & $4 \pm 8$ & $20 \pm 10$ & $5 \pm 7$ & $10 \pm 13$ \\
\hline
\end{tabular}

Data represent mean \pm SD of the sum of USV emitted during the first 20s period of each 1-min interval of the 20-min test length.

${ }^{\mathrm{a}} \mathrm{p}<0.05$ compared to all other groups.

in the levels of GSH (Fig. 3C).

In the PFC, two-way ANOVA showed effects of repeated treatment $\left(\mathrm{F}_{2,37}=3.36, \mathrm{p}<0.05\right)$ and LDX administration $\left(\mathrm{F}_{1,37}=7.59, \mathrm{p}<0.01\right)$ but not repeated treatment-LDX administration interaction $\left(\mathrm{F}_{1,37}=\right.$ 0.20 , NS). The Newman-Keuls test indicated that LDX administration decreased GSH levels in rat PFC independently from ANDRO or lithium treatment $(\mathrm{p}<0.01$; saline $=28 \pm 23$ and $\mathrm{LDX}=14 \pm 9$, mean $\pm \mathrm{SD}, \mathrm{n}$ $=22$ and 21, respectively; Fig. 3D).

\subsection{Correlations}

The Pearson's correlation coefficient showed positive correlations between LPO levels in rat striatum with $50-\mathrm{kHz}$ USV calls $(\mathrm{r}=0.62, \mathrm{p}<$
Fig. 2. Effects of 21 days treatment with lithium (100 mg/kg i.p.), andrographolide (ANDRO, $2 \mathrm{mg}$ / $\mathrm{kg}$ i.p.) or vehicle on lisdexamfetamine (LDX, 10 $\mathrm{mg} / \mathrm{kg}$ i.p.)-induced increase in the number $50-\mathrm{kHz}$ USV calls (A) and locomotor activity (B). Vehicle: saline + DMSO. Data are expressed by mean \pm SD. $\mathrm{n}=5-8$ rats/group. ${ }^{* * *} \mathrm{p}<0.001$, compared with rats treated with vehicle + saline; ${ }^{\# \#} \mathrm{p}<0.01$ and \#\#\# $\mathrm{p}<0.001$, compared to the vehicle + LDX (twoway ANOVA followed by the Newman-Keuls test).
0.001 ) and with locomotor activity ( $r=0.61, \mathrm{p}<0.001$; Fig. 4).Moreover, there was also a positive correlation between locomotor activity and $50 \mathrm{kHz}$ USV $(\mathrm{r}=0.62, \mathrm{p}<0.001)$. On the other hand, no correlation was observed between LPO levels in PFC with $50-\mathrm{kHz}$ USV calls ( $\mathrm{r}=$ $-0.11, \mathrm{NS})$ and with locomotor activity ( $\mathrm{r}=-0.03$, NS; data not shown).

\section{Discussion}

The present study showed that repeated treatment with ANDRO prevented LDX-induced manic-like behaviors (hyperlocomotion and increases in 50-kHz USV) and striatal LPO levels. Similar results were obtained with repeated treatment with lithium, a clinically effective antimanic drug, which was used as a positive control. These results suggest that ANDRO possesses an antimanic-like behavioral effect and exerts antioxidant activity in the LDX model of mania.

The administration of psychostimulants (e.g., d-amphetamine) is a common method for inducing manic-like behavior in animal models, such as hyperlocomotion and increases in $50 \mathrm{kHz}$ USV (Young et al., 2011; Sharma et al., 2016; de Miranda et al., 2017). LDX is a long-acting pro-drug of d-amphetamine employed in the therapeutic management of attention deficit/hyperactivity disorder (Ermer et al., 2016). LDX administration has also been used to mimic manic-like behavior in animals (Macêdo et al., 2013; de Souza et al., 2015; Eger et al., 2016; Wendler et al., 2016; Ascoli et al., 2017; Bristot et al., 2019). These manic-like behaviors were reversed or prevented by treatment with lithium or valproate (Macêdo et al., 2013; de Souza et al., 2015; Wendler et al., 2016; Ascoli et al., 2017; Bristot et al., 2019). LDX administration also increases oxidative stress (Macêdo et al., 2013; de Souza et al., 


\section{Striatum}

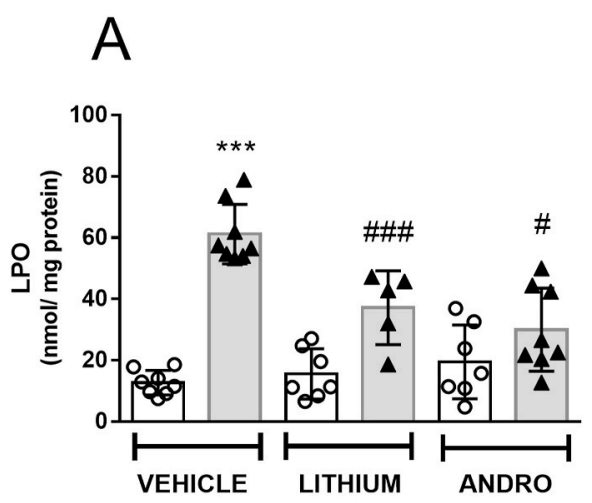

C

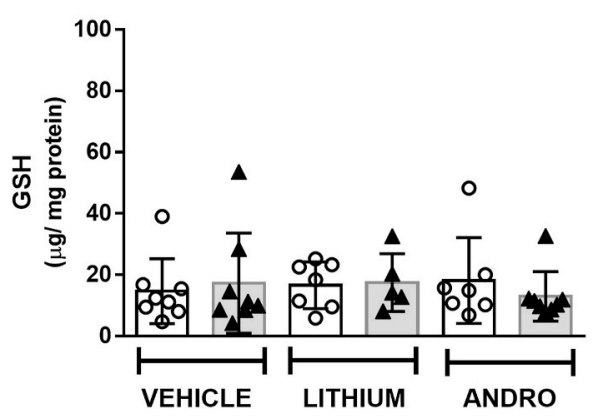

PFC
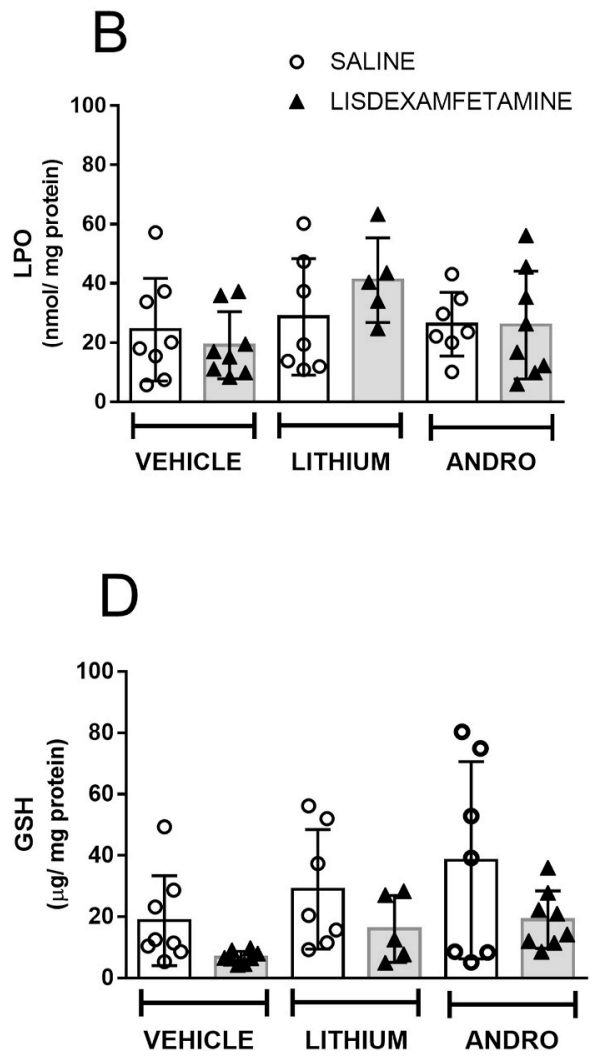

Fig. 3. Effects of 21 days treatment with Lithium (100 mg/kg i.p.), Andrographolide (ANDRO, $2 \mathrm{mg}$ / $\mathrm{kg}$ i.p.) or vehicle on lisdexamfetamine (LDX, 10 $\mathrm{mg} / \mathrm{kg}$ i.p.) induced changes in reduced glutathione (GSH) and lipid peroxidation (LPO) levels in the prefrontal cortex (PCF) and striatum, respectively. (A) LPO levels in the striatum. (B) LPO levels in the PFC; (C) GSH levels in the striatum; (D) GSH levels in the PFC. Data are expressed by mean \pm SD. $n=$ 5-8 rats/group. ${ }^{* * *} \mathrm{p}<0.001$, compared with rats treated with vehicle + vehicle; ${ }^{\#} \mathrm{p}<0.05$ and ${ }^{\# \# \#} \mathrm{p}$ $<0.001$, compared with rats treated with vehicle + LDX. Two-way ANOVA followed by the NewmanKeuls test.
2015; Eger et al., 2016), as observed in plasma as well as serum of bipolar patients in manic state (Machado-Vieira et al., 2007; Caldiroli et al., 2020). Thus, the LDX model is a valid procedure for the study of mania and antimanic-like drugs. In the present study, repeated ANDRO and lithium administration prevented LDX-induced hyperlocomotion at a dose that did not affect spontaneous locomotor activity, a profile suggestive of an antimanic-like effect (Young et al., 2011).

In addition to hyperlocomotion, LDX administration also induced an increase in 50-kHz USV. Juvenile and adult rats emit high-frequency 50$\mathrm{kHz}$ USV in appetitive situations, such as playing with other rats, mating or after psychostimulant administration (e.g. Burgdorf et al., 2011; Rippberger et al., 2015) Therefore, it is proposed that $50-\mathrm{kHz}$ can represent a positive affective state in rats (Wöhr and Schwarting, 2013; Barker, 2018; Simola, 2018), and that they can be used to monitor hedonic states in animal models of various psychiatric disorders (Burgdorf et al., 2011). In this line, 50-kHz USV were found to be increased in different animal models of mania such as amphetamine or LDX administration, and sleep deprivation (Pereira et al., 2014; Wendler et al., 2016, 2019; Engelhardt et al., 2017). This increase in 50-kHz USV was blocked by the antimanic drugs lithium, tamoxifen and antipsychotics (Wintink and Brudzynski, 2001; Pereira et al., 2014; Barker et al., 2015; Wendler et al., 2016, 2019). Thus, 50-kHz USV have been proposed as a new marker in animal models of mania, representing the increase in the positive affect and/or elevated mood (Wendler et al., 2016; Engelhardt et al., 2017; de Miranda et al., 2017; Wendler et al., 2019; for review, see Wöhr, 2021). In the present study, repeated treatment with ANDRO and lithium prevented LDX effects in the number of $50-\mathrm{kHz}$ calls, and in the number of trill and flat calls subtypes. ANDRO and lithium alone did not affect $50-\mathrm{kHz}$ USV. These results indicate an antimanic-like effect of ANDRO on $50-\mathrm{kHz}$ USV.

Considering some similarities between the effects of LDX on locomotor activity and USV (e.g. increase after LDX administration, blockade by lithium and ANDRO pretreatment) and close correlation coefficients with LPO, it could be hypothesized that locomotor and USV responses to psychostimulant are redundant and interchangeable variables. However, in the present study USV and locomotor activity showed a moderate coefficient of correlation $(r=0.62)$ and previous studies showed that USV and locomotor activity peaked differently after amphetamine administration and showed a different pattern after repeated administration of amphetamine (Natusch and Schwarting, 2010; Simola, 2018). Thus, these variables can be considered different facets of manic-like behavior (Wendler et al., 2019).

The present study also shows that LDX administration can lead to increased LPO in striatum and decreased GSH levels in PFC. Repeated lithium and ANDRO treatment prevented LDX-induced increases in LPO in rat striatum. Increased generation of reactive oxygen species and free radicals are involved in the pathophysiology of bipolar disorder, as increases in serum/plasma LPO occur in different phases and are associated to illness severity and/or the number of manic episodes (Andreazza et al., 2007; Machado-Vieira et al., 2007; Brown et al., 2014; Sowa-Kućma et al., 2018; Akarsu et al., 2018). In this line, high concentrations of phospholipids make brain tissues more vulnerable to oxidative stress induced by LPO (Banerjee et al., 2012). Lipid hydroperoxide chain reactions eventually cause the formation of reactive aldehydes and this can damage lipid membranes (Maes et al., 2018). Increased oxidative stress leads to derangement of signal transduction, structural plasticity and cellular resilience in brain tissue (Schäfer et al., 2004). Lv et al. (2020) showed that LPO levels were higher in the plasma of treatment-resistant bipolar disorder patients and decreased after 6 weeks of electroconvulsive therapy.

Oxidative stress in the brain was observed in different models of mania such as psychostimulants (Frey et al., 2006; Sharma et al., 2016; Hodes et al., 2018; Valvassori et al., 2019; Chaves Filho et al., 2020), ouabain (Valvassori et al., 2017; Dal Pont et al., 2019), sleep deprivation 
A

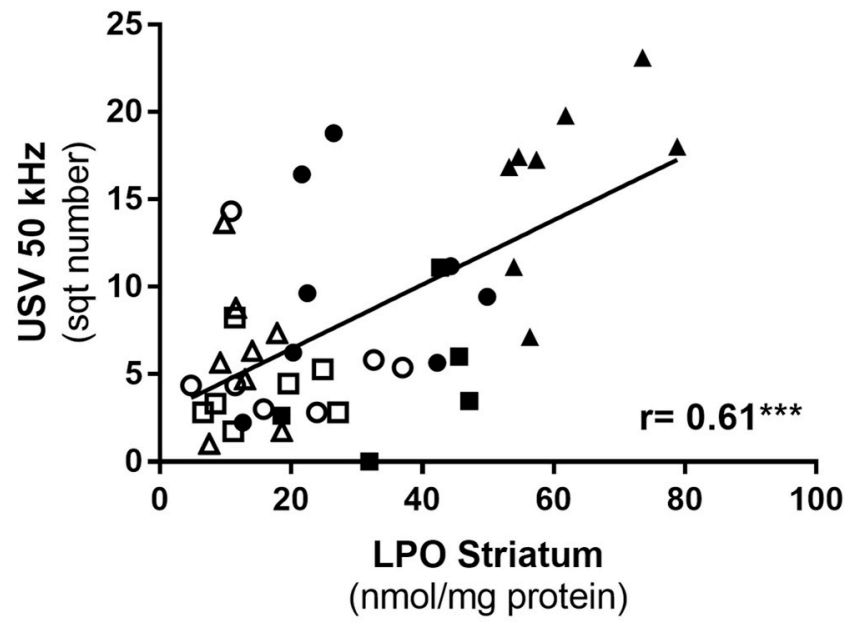

B

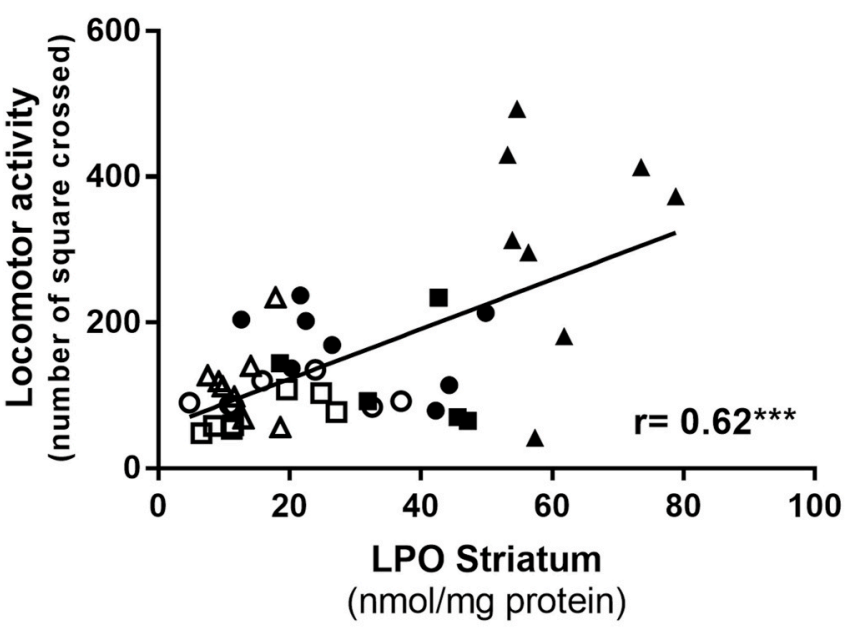

C

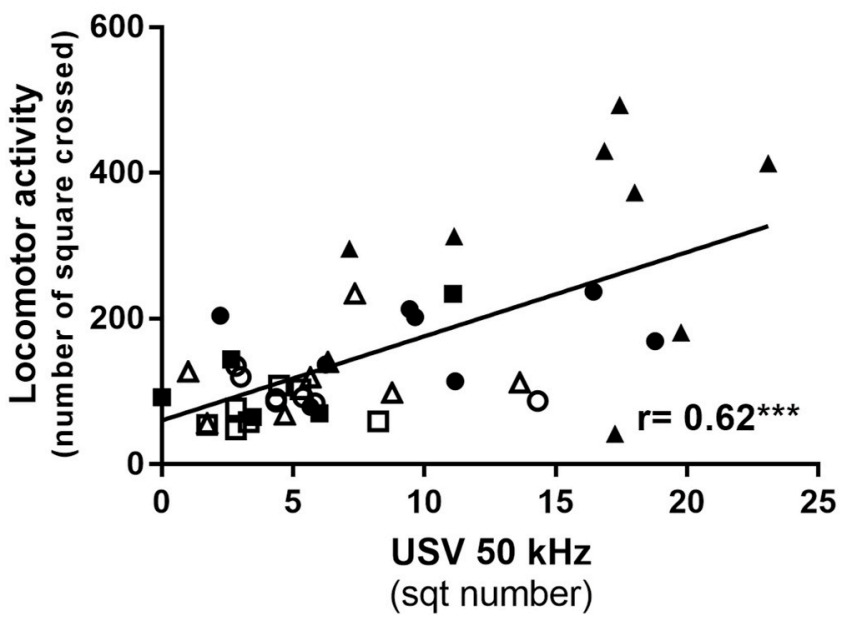

Fig. 4. Correlations between locomotor activity, $50-\mathrm{kHz}$ ultrasonic vocalization (USV) and striatal lipid peroxidation (LPO) in the lisdexamfetamine model of mania. (A) USV and LPO; (B) Locomotor activity and LPO; (C) USV and locomotor Activity. Acute treatment: vehicle: open symbols; lisdexamfetamine (10 $\mathrm{mg} / \mathrm{kg}$ ): closed symbols. Repeated treatment: vehicle: triangle; lithium (100 $\mathrm{mg} / \mathrm{kg}$ ): square; andrographolide $(2 \mathrm{mg} / \mathrm{kg})$ : circle. Pearson correlation coefficient, $* * * \mathrm{p}<0.001$.
(Kanazawa et al., 2016) and ketamine (Garzal et al., 2014). The observation that mood stabilizing agents such as lithium and sodium valproate also exert antioxidant effects, reinforces the idea that oxidative stress is involved in the pathophysiology and treatment of mania (Andreazza et al., 2007; Banerjee et al., 2012; Brown et al., 2014; Kanazawa et al., 2016; Valvassori et al., 2017; de Queiroz et al., 2018). However, the antioxidant effects of lithium may be specific to certain brain regions and these can vary depending on experimental variables including type of drug and age of animals (Chaves Filho et al., 2020; Schmitz et al., 2012). Particularly to LDX, it increased LPO in rat PFC, hippocampus and striatum, and lithium and valproate prevented and reversed the effects of repeated LDX administration on LPO in these brain areas (Macêdo et al., 2013; de Souza et al., 2015). In the present study, acute LDX administration increased LPO levels in the striatum, but not in the PFC. Treatment with ANDRO and lithium reduced this effect of LDX in striatal LPO levels. In addition, there was a positive correlation between LPO levels in rat striatum and increases in $50-\mathrm{kHz}$ USV, as well as LDX-induced hyperlocomotion. Menegas et al. (2020), using the methamphetamine administration model of mania, also observed correlations between hyperlocomotion and lipid damage parameters in the striatum of rats. Clinically, a positive correlation between mania severity (Young Mania Rating Scale) and peripheral oxidative stress index was also (Akarsu et al., 2018) observed which supports the relevance of our pre-clinical approach.

GSH is a non-enzymatic antioxidant molecule and its depletion can lead to neuronal dysfunctions and various disorders (Gaucher et al., 2018). In the present study, LDX administration reduced GSH levels in rat PFC. ANDRO and lithium treatment, however, had no effects on LDX-induced decrease on GSH level. Studies also showed divergent results regarding GSH levels in the brain. Macêdo et al. (2013), for example, showed that LDX administration induced hyperlocomotion and decreased GSH content in rat PFC and striatum, which was prevented by lithium in both brain areas. However, only lithium reversed the reduction of GSH in the PFC. These heterogeneous results can be dependent of methodological differences including subjects, experimental protocol or acute/repeated drug administration.

The antimanic effect of lithium has been partly related to its inhibitory activity on the enzyme GSK3 $\beta$, which has been linked to oxidative stress in mania models (Dal Pont et al., 2019). AR-A014418, a GSK3 $\beta$ inhibitor, reverted ouabain-induced hyperlocomotion and oxidative stress in frontal cortex and hippocampus of rats (Dal Pont et al., 2019). In this line, ANDRO also inhibits GSK3 $\beta$ (Serrano et al., 2014; Varela-Nellar et al., 2015) and, thus, inhibition of GSK3 $\beta$ may also contribute to the antimanic-like effect of ANDRO observed in the present study.

In conclusion, the present results suggest that ANDRO possesses antimanic-like effects in the LDX-administration model of mania, preventing LDX-induced increases in 50-kHz USV and hyperlocomotion, and its antioxidant effects may mediate these effects.

\section{Author statement}

Luiz KS Kanazawa: conceptualization; methodology; performing experiments; data analysis; writing, reviewing and editing the manuscript. Débora R Radulski: performing experiments. Gabriela S. Pereira: performing experiments. Jos Prickaerts: data interpretation; writing, reviewing and editing the manuscript. RKW Schwarting: conceptualization; methodology; data interpretation; writing, reviewing and editing the manuscript. Alexandra Acco: data analysis and interpretation; writing, reviewing and editing the manuscript. Roberto Andreatini: conceptualization, methodology, data analysis and interpretation; writing, reviewing and editing the manuscript.

\section{Role of the funding source}

This study was financed in part by Conselho Nacional de Desenvolvimento Científico e Tecnológico (CNPq), the Brazil-The Netherlands 
cooperation program CAPES-NUFFIC, SCHW 559/14-2 from the Deutsche Forschungsgemeinschaft (DFG) and project 57446778 of the PPP program of the Deutsche Akademische Austauschdienst (DAAD). These agencies had no further role in study design; in the collection, analysis and interpretation of data; in the writing of the report; and in the decision to submit the paper for publication.

\section{Declaration of competing interest}

The authors declare no conflicts of interest related to this study.

\section{Acknowledgements}

RA is recipient of a research fellowship from CNPq and LKSK was recipient of a PhD fellowship from Coordenação de Aperfeiçoamento de Pessoal de Nível Superior (CAPES, Brasil; Finance Code 001).

\section{References}

Akarsu, S., Bolu, A., Aydemir, E., Zincir, S.B., Kurt, Y.G., Zincir, S., Erdem, M., Uzun, Ö. 2018. The relationship between the number of manic episodes and oxidative stress indicators in Bipolar Disorder. Psychiatr. Invest. 15 (5), 514-519. https://doi.org/ 10.30773/pi.2016.12.31.

American Psychiatry Association, 2013. Diagnostic and Statistical Manual of Mental Disorders: DSM-5. American Psychiatric Association, Washington.

Andreazza, A.C., Cassini, C., Rosa, A.R., Leite, M.C., de Almeida, L.M., Nardin, P., Cunha, A.B., Ceresér, K.M., Santin, A., Gottfried, C., Salvador, M., Kapczinski, F., Gonçalves, C.A., 2007. Serum S100B and antioxidant enzymes in bipolar patients. J. Psychiatr. Res. 41 (6), 523-529. https://doi.org/10.1016/j. jpsychires.2006.07.013.

Arunagiri, P., Rajeshwaran, K., Shanthakumar, J., Tamilselvan, T., Balamurugan, E., 2014. Combination of omega-3 Fatty acids, lithium, and aripiprazole reduces oxidative stress in brain of mice with mania. Biol. Trace Elem. Res. 160 (3), 409-417. https://doi.org/10.1007/s12011-014-0067-8.

Ascoli, B.M., Colombo, R., Géa, L.P., Terraciano, P.B., Pizzato, S.B., de Oliveira, F.S., Cirne-Lima, E., Kapczinski, F., Rosa, A.R., 2017. Cell therapy in the treatment of bipolar mania in an animal model: a proof of concept study. Trends Psychiatr. Psychother. 39 (3), 196-201. https://doi.org/10.1590/2237-6089-2016-0074.

Baldessarini, R.J., Tondo, L., Vázquez, G.H., 2019. Pharmacological treatment of adult bipolar disorder. Mol. Psychiatr. 24 (2), 198-217. https://doi.org/10.1038/s41380018-0044-2.

Banerjee, U., Dasgupta, A., Rout, J.K., Singh, O.P., 2012. Effects of lithium therapy on Na +-K+-ATPase activity and lipid peroxidation in bipolar disorder. Prog. NeuroPsychopharmacol. Biol. Psychiatry 37 (1), 56-61. https://doi.org/10.1016/j. pnpbp.2011.12.006.

Barker, D.J., Simmons, S.J., West, M.O., 2015. Ultrasonic vocalizations as a measure of affect in preclinical models of drug abuse: a review of current findings. Curr. Neuropharmacol. 13 (2), 193-210. https://doi.org/10.2174/ 1570159x13999150318113642.

Barker, D.J., 2018. Effects of psychostimulants on rat emotional states and emission of ultrasonic vocalization. In: Brudzynski, S.M. (Ed.), Handbook of Ultrasonic Vocalization: A Window into the Emotional Brain. Academic Press, London, pp. 281-293.

Bradford, M.M., 1976. A rapid and sensitive method for the quantitation of microgram quantities of protein utilizing the principle of protein-dye binding. Anal. Biochem. 72, 248-254. https://doi.org/10.1006/abio.1976.9999.

Bristot, G., Ascoli, B.M., Scotton, E., Géa, L.P., Pfaffenseller, B., Kauer-Sant'Anna, M., 2019. Effects of lithium on inflammatory and neurotrophic factors after an immune challenge in a lisdexamfetamine animal model of mania. Br. J. Psychiatr. 41 (5), 419-427. https://doi.org/10.1590/1516-4446-2017-0001.

Brocardo, P.S., Budni, J., Pavesi, E., Franco, J.L., Uliano-Silva, M., Trevisan, R., Terenzi, M.G., Dafre, A.L., Rodrigues, A.L., 2010. Folic acid administration prevents ouabain-induced hyperlocomotion and alterations in oxidative stress markers in the rat brain. Bipolar Disord. 12 (4), 414-424. https://doi.org/10.1111/j.13995618.2010.00827.x.

Brown, N.C., Andreazza, A.C., Young, L.T., 2014. An updated meta-analysis of oxidative stress markers in bipolar disorder. Psychiatr. Res. 218 (1-2), 61-68. https://doi.org/ 10.1016/j.psychres.2014.04.005.

Burgdorf, J., Panksepp, J., Moskal, J.R., 2011. Frequency-modulated 50 kHz ultrasonic vocalizations: a tool for uncovering the molecular substrates of positive affect. Neurosci. Biobehav. Rev. 35 (9), 1831-1836. https://doi.org/10.1016/j. neubiorev.2010.11.011.

Caldiroli, A., Auxilia, A.M., Capuzzi, E., Clerici, M., Buoli, M., 2020. Malondialdehyde and bipolar disorder: a short comprehensive review of available literature. J. Affect. Disord. 274, 31-37. https://doi.org/10.1016/j.jad.2020.05.001.

Chan, S.J., Wong, W.S., Wong, P.T., Bian, J.S., 2010. Neuroprotective effects of andrographolide in a rat model of permanent cerebral ischaemia. Br. J. Pharmacol. 161 (3), 668-679. https://doi.org/10.1111/j.1476-5381.2010.00906.x.

Chaves Filho, A.J.M., Cunha, N.L., Rodrigues, P.A., de Souza, A.G., Soares, M.V., Jucá, P. M., de Queiroz, T., Clemente, D.C.D.S., Mottin, M., Andrade, C.H., Peixoto, C.A.,
Macedo, D.S., 2020. Doxycycline reverses cognitive impairment, neuroinflammation and oxidative imbalance induced by D-amphetamine mania model in mice: a promising drug repurposing for bipolar disorder treatment? Eur. Neuropsychopharmacol. S0924-977X (20), 30939-1 https://doi.org/10.1016/j. euroneuro.2020.11.007.

Costa, G., Serra, M., Marongiu, J., Morelli, M., Simola, N., 2020. Influence of dopamine transmission in the medial prefrontal cortex and dorsal striatum on the emission of $50-\mathrm{kHz}$ ultrasonic vocalizations in rats treated with amphetamine: effects on drugstimulated and conditioned calls. Prog. Neuropsychopharmacol. Biol. Psychiatry 97, 109797. https://doi.org/10.1016/j.pnpbp.2019.109797.

Dal-Pont, G.C., Jório, M.T.S., Resende, W.R., Gava, F.F., Aguiar-Geraldo, J.M., PossamaiDella, T., Peper-Nascimento, J., Quevedo, J., Valvassori, S.S., 2019a. Effects of lithium and valproate on behavioral parameters and neurotrophic factor levels in an animal model of mania induced by paradoxical sleep deprivation. J. Psychiatr. Res. 119, 76-83. https://doi.org/10.1016/j.jpsychires.2019.09.003.

Dal-Pont, G.C., Resende, W.R., Varela, R.B., Menegas, S., Trajano, K.S., Peterle, B.R., Quevedo, J., Valvassori, S.S., 2019b. Inhibition of GSK-3 $\beta$ on behavioral changes and oxidative stress in an animal model of mania. Mol. Neurobiol. 56 (4), 2379-2393. https://doi.org/10.1007/s12035-018-1226-2.

Dandekar, M.P., Valvassori, S.S., Dal-Pont, G.C., Quevedo, J., 2018. Glycogen synthase kinase-3 $\beta$ as a putative therapeutic target for bipolar disorder. Curr. Drug Metabol. 19 (8), 663-673. https://doi.org/10.2174/1389200219666171227203737.

de Miranda, A.S., Andreatini, R., Teixeira, A.L., 2017. Animal models of mania: essential tools to better understand bipolar disorder. In: Michael Conn, P. (Ed.), Animal Models for the Study of Human Disease, second ed. Academic Press, London, pp. 1131-1143.

de Queiroz, A.I.G., Chaves Filho, A.J.M., Araújo, T.D.S., Lima, C.N.C., Machado, M.J.S., Carvalho, A.F., Vasconcelos, S.M.M., de Lucena, D.F., Quevedo, J., Macedo, D., 2018. Antimanic activity of minocycline in a GBR12909-induced model of mania in mice: possible role of antioxidant and neurotrophic mechanisms. J. Affect. Disord. 225, 40-51. https://doi.org/10.1016/j.jad.2017.07.053.

de Souza, G.C., Gomes, J.A., de Góis Queiroz, A.I., de Araújo, M.M., Cavalcante, L.M., de Machado, M., Monte, A.S., de Lucena, D.F., Quevedo, J., Carvalho, A.F., Macêdo, D., 2015. Preclinical evidences for an antimanic effect of carvedilol. Neural Plast., 692541 https://doi.org/10.1155/2015/692541.

Eger, G.A., Ferreira, V.V., Batista, C.R., Bonde, H., de Lima, D.D., Wyse, A.T., da Cruz, J. N., Rodrigues, A.F., Magro, D.D., da Cruz, J.G., 2016. Antioxidant effect of simvastatin throught oxidative imbalance caused by lisdexamfetamine dimesylate. An. Acad. Bras. Cienc. 88 (1), 335-348. https://doi.org/10.1590/0001 3765201620140490.

Engelhardt, K.A., Fuchs, E., Schwarting, R.K.W., Wöhr, M., 2017. Effects of amphetamine on pro-social ultrasonic communication in juvenile rats: implications for mania models. Eur. Neuropsychopharmacol. 27 (3), 261-273. https://doi.org/10.1016/j. euroneuro.2017.01.003.

Ermer, J.C., Pennick, M., Frick, G., 2016. Lisdexamfetamine dimesylate: prodrug delivery, amphetamine exposure and duration of efficacy. Clin. Drug Invest. 36 (5), 341-356. https://doi.org/10.1007/s40261-015-0354-y.

Frey, B.N., Valvassori, S.S., Réus, G.Z., Martins, M.R., Petronilho, F.C., Bardini, K., DalPizzol, F., Kapczinski, F., Quevedo, J., 2006. Effects of lithium and valproate on amphetamine-induced oxidative stress generation in an animal model of mania J. Psychiatry Neurosci. 31 (5), 326-332.

Gaucher, C., Boudier, A., Bonetti, J., Clarot, I., Leroy, P., Parent, M., 2018. Glutathione: antioxidant properties dedicated to nanotechnologies. Antioxidants (Basel) 7 (5), 62. https://doi.org/10.3390/antiox7050062.

Gazal, M., Valente, M.R., Acosta, B.A., Kaufmann, F.N., Braganhol, E., Lencina, C.L. Stefanello, F.M., Ghisleni, G., Kaster, M.P., 2014. Neuroprotective and antioxidant effects of curcumin in a ketamine-induced model of mania in rats. Eur. J. Pharmacol. 724, 132-139. https://doi.org/10.1016/j.ejphar.2013.12.028.

Geddes, J.R., Miklowitz, D.J., 2013. Treatment of bipolar disorder. Lancet 381 (9878), 1672-1682. https://doi.org/10.1016/S0140-6736(13)60857-0.

Hodes, A., Lifschytz, T., Rosen, H., Cohen Ben-Ami, H., Lichtstein, D., 2018. Reduction in endogenous cardiac steroids protects the brain from oxidative stress in a mouse model of mania induced by amphetamine. Brain Res. Bull. 137, 356-362. https:// doi.org/10.1016/j.brainresbull.2018.01.016.

Jiang, Z.Y., Hunt, J.V., Wolff, S.P., 1992. Ferrous ion oxidation in the presence of xylenol orange for detection of lipid hydroperoxide in low density lipoprotein. Anal. Biochem. 202 (2), 384-389. https://doi.org/10.1016/0003-2697(92)90122-n.

Kanazawa, L.K.S., Vecchia, D.D., Wendler, E.M., Hocayen, P.A.S., Dos Reis Lívero, F.A., Stipp, M.C., Barcaro, I.M.R., Acco, A., Andreatini, R., 2016. Quercetin reduces manic-like behavior and brain oxidative stress induced by paradoxical sleep deprivation in mice. Free Radic. Biol. Med. 99, 79-86. https://doi.org/10.1016/j. freeradbiomed.2016.07.027.

Li, X., Liu, M., Cai, Z., Wang, G., Li, X., 2010. Regulation of glycogen synthase kinase-3 during bipolar mania treatment. Bipolar Disord. 12 (7), 741-752. https://doi.org/ 10.1111/j.1399-5618.2010.00866.x.

Lim, J.C., Chan, T.K., Ng, D.S., Sagineedu, S.R., Stanslas, J., Wong, W.S., 2012. Andrographolide and its analogues: versatile bioactive molecules for combating inflammation and cancer. Clin. Exp. Pharmacol. Physiol. 39 (3), 300-310. https:/ doi.org/10.1111/j.1440-1681.2011.05633.x.

Lv, Q., Hu, Q., Zhang, W., Huang, X., Zhu, M., Geng, R., Cheng, X., Bao, C., Wang, Y., Zhang, C., He, Y., Li, Z., Yi, Z., 2020. Disturbance of oxidative stress parameters in treatment-resistant bipolar disorder and their association with electroconvulsive therapy response. Int. J. Neuropsychopharmacol. 23 (4), 207-216. https://doi.org/ 10.1093/ijnp/pyaa003.

Macêdo, D.S., de Lucena, D.F., Queiroz, A.I., Cordeiro, R.C., Araújo, M.M., Sousa, F.C., Vasconcelos, S.M., Hyphantis, T.N., Quevedo, J., McIntyre, R.S., Carvalho, A.F., 
2013. Effects of lithium on oxidative stress and behavioral alterations induced by lisdexamfetamine dimesylate: relevance as an animal model of mania. Prog. NeuroPsychopharmacol. Biol. Psychiatry 43, 230-237. https://doi.org/10.1016/j. pnpbp.2013.01.007.

Machado-Vieira, R., Andreazza, A.C., Viale, C.I., Zanatto, V., Cereser Jr., V., da Silva Vargas, R., Kapczinski, F., Portela, L.V., Souza, D.O., Salvador, M., Gentil, V., 2007. Oxidative stress parameters in unmedicated and treated bipolar subjects during initial manic episode: a possible role for lithium antioxidant effects. Neurosci. Lett. 421 (1), 33-36. https://doi.org/10.1016/j.neulet.2007.05.016.

Maes, M., Landucci Bonifacio, K., Morelli, N.R., Vargas, H.O., Barbosa, D.S., Carvalho, A F., Nunes, S.O.V., 2019. Major differences in neurooxidative and neuronitrosative stress pathways between major depressive disorder and types I and II bipolar disorder. Mol. Neurobiol. 56 (1), 141-156. https://doi.org/10.1007/s12035-018 1051-7.

Malhi, G.S., Tanious, M., Das, P., Coulston, C.M., Berk, M., 2013. Potential mechanisms of action of lithium in bipolar disorder. Current understanding. CNS Drugs 27 (2), 135-153. https://doi.org/10.1007/s40263-013-0039-0.

Menegas, S., Dal-Pont, G.C., Cararo, J.H., Varela, R.B., Aguiar-Geraldo, J.M., PossamaiDella, T., Andersen, M.L., Quevedo, J., Valvassori, S.S., 2020. Efficacy of folic acid as an adjunct to lithium therapy on manic-like behaviors, oxidative stress and inflammatory parameters in an animal model of mania. Metab. Brain Dis. 35 (2), 413-425. https://doi.org/10.1007/s11011-019-00503-3.

Mittal, S.P.K., Khole, S., Jagadish, N., Ghosh, D., Gadgil, V., Sinkar, V., Ghaskadbi, S.S. 2016. Andrographolide protects liver cells from $\mathrm{H} 2 \mathrm{O} 2$ induced cell death by upregulation of Nrf-2/HO-1 mediated via adenosine A2a receptor signalling. Biochim. Biophys. Acta 1860 (11 Pt A), 2377-2390. https://doi.org/10.1016/j. bbagen.2016.07.005.

Mulvihill, K.G., Brudzynski, S.M., 2020. Association of medial corticostriatal regions with amphetamine-induced emission of $50 \mathrm{kHz}$ vocalizations as studied by Zif-268 expression in the rat brain. Brain Res 1726, 146505. https://doi.org/10.1016/j. brainres.2019.146505

Natusch, C., Schwarting, R.K., 2010. Using bedding in a test environment critically affects $50-\mathrm{kHz}$ ultrasonic vocalizations in laboratory rats. Pharmacol. Biochem. Behav. 96 (3), 251-259. https://doi.org/10.1016/j.pbb.2010.05.013.

Niranjan, A., Tewari, S.K., lehri, A., 2010. Biological activities of Kalmegh (Andrographi paniculata Nees) and its active principles - a review. Indian J. Nat. Prod. Resour. 1 (2), 125-135.

Pereira, M., Andreatini, R., Schwarting, R.K., Brenes, J.C., 2014. Amphetamine-induced appetitive $50-\mathrm{kHz}$ calls in rats: a marker of affect in mania? Psychopharmacology (Berlin) 231 (13), 2567-2577. https://doi.org/10.1007/s00213-013-3413-1.

Prickaerts, J., Moechars, D., Cryns, K., Lenaerts, I., van Craenendonck, H., Goris, I., Daneels, G., Bouwknecht, J.A., Steckler, T., 2006. Transgenic mice overexpressing glycogen synthase kinase 3beta: a putative model of hyperactivity and mania. J. Neurosci. 26 (35), 9022-9029. https://doi.org/10.1523/JNEUROSCI.521605.2006

Rippberger, H., van Gaalen, M.M., Schwarting, R.K., Wohr, M., 2015. Environmental and pharmacological modulation of amphetamine- induced $50-\mathrm{kHz}$ ultrasonic vocalizations in rats. Curr. Neuropharmacol. 13 (2), 220-232. https://doi.org/ 10.2174/1570159x1302150525124408.

Saxena, A., Scaini, G., Bavaresco, D.V., Leite, C., Valvassori, S.S., Carvalho, A.F., Quevedo, J., 2017. Role of protein kinase C in Bipolar Disorder: a review of the current literature. Mol. Neuropsychiatr. 3 (2), 108-124. https://doi.org/10.1159/ 000480349.

Schäfer, M., Goodenough, S., Moosmann, B., Behl, C., 2004. Inhibition of glycogen synthase kinase 3 beta is involved in the resistance to oxidative stress in neuronal HT22 cells. Brain Res. 1005 (1-2), 84-89. https://doi.org/10.1016/j. brainres.2004.01.037.

Schmitz, F., Scherer, E.B., Machado, F.R., da Cunha, A.A., Tagliari, B., Netto, C.A., Wyse, A.T., 2012. Methylphenidate induces lipid and protein damage in prefrontal cortex, but not in cerebellum, striatum and hippocampus of juvenile rats. Metab. Brain Dis. 27 (4), 605-612. https://doi.org/10.1007/s11011-012-9335-5.

Sedlak, J., Lindsay, R.H., 1968. Estimation of total, protein-bound, and nonprotein sulfhydryl groups in tissue with Ellman's reagent. Anal. Biochem. 25 (1), 192-205. https://doi.org/10.1016/0003-2697(68)90092-4.

Serrano, F.G., Tapia-Rojas, C., Carvajal, F.J., Hancke, J., Cerpa, W., Inestrosa, N.C., 2014 Andrographolide reduces cognitive impairment in young and mature A $\beta P P$ swe/PS-1 mice. Mol. Neurodegener. 9, 61. https://doi.org/10.1186/1750-1326-9-61.
Sharma, A.N., Fries, G.R., Galvez, J.F., Valvassori, S.S., Soares, J.C., Carvalho, A.F., Quevedo, J., 2016. Modeling mania in preclinical settings: a comprehensive review. Prog. Neuro-Psychopharmacol. Biol. Psychiatry 66, 22-34. https://doi.org/10.1016/ j.pnpbp.2015.11.001.

Simola, N., 2018. Effects of psychostimulants on rat emotional states and emission of ultrasonic vocalizations. In: Brudzynski, S.M. (Ed.), Handbook of Ultrasonic Vocalization: A Window into the Emotional Brain. Academic Press, London, pp. 281-293. https://doi.org/10.1016/B978-0-12-809600-0.00027-5.

Simola, N., Brudzynski, S.M., 2018. Repertoire and biological function of ultrasonic vocalizations in adolescent and adult rats. In: Brudzynski, S.M. (Ed.), Handbook of Ultrasonic Vocalization: A Window into the Emotional Brain. Academic Press, London, pp. 177-186. https://doi.org/10.1016/B978-0-12-809600-0.00017-2.

Sowa-Kućma, M., Styczeń, K., Siwek, M., Misztak, P., Nowak, R.J., Dudek, D. Rybakowski, J.K., Nowak, G., Maes, M., 2018. Are there differences in lipid peroxidation and immune biomarkers between major depression and bipolar disorder: effects of melancholia, atypical depression, severity of illness, episode number, suicidal ideation and prior suicide attempts. Prog. Neuro-Psychopharmacol. Biol. Psychiatry 81, 372-383. https://doi.org/10.1016/j.pnpbp.2017.08.024.

Tan, W.S., Peh, H.Y., Liao, W., Pang, C.H., Chan, T.K., Lau, S.H., Chow, V.T., Wong, W.S., 2016. Cigarette smoke-induced lung disease predisposes to more severe infection with nontypeable Haemophilus influenzae: protective effects of andrographolide. J. Nat. Prod. 79 (5), 1308-1315. https://doi.org/10.1021/acs.jnatprod.5b01006.

Valvassori, S.S., Resende, W.R., Dal-Pont, G., Sangaletti-Pereira, H., Gava, F.F., Peterle, B.R., Carvalho, A.F., Varela, R.B., Dal-Pizzol, F., Quevedo, J., 2017. Lithium ameliorates sleep deprivation-induced mania-like behavior, hypothalamic-pituitaryadrenal (HPA) axis alterations, oxidative stress and elevations of cytokine concentrations in the brain and serum of mice. Bipolar Disord. 19 (4), 246-258. https://doi.org/10.1111/bdi.12503.

Valvassori, S.S., Tonin, P.T., Dal-Pont, G.C., Varela, R.B., Cararo, J.H., Garcia, A.F., Gava, F.F., Menegas, S., Soares, J.C., Quevedo, J., 2019. Coadministration of lithium and celecoxib reverses manic-like behavior and decreases oxidative stress in a dopaminergic model of mania induced in rats. Transl. Psychiatry 9 (1), 297. https:// doi.org/10.1038/s41398-019-0637-9.

Varela-Nallar, L., Arredondo, S.B., Tapia-Rojas, C., Hancke, J., Inestrosa, N.C., 2015. Andrographolide stimulates neurogenesis in the adult hippocampus. Neural Plast., 935403 https://doi.org/10.1155/2015/935403.

Wendler, E., de Souza, C.P., Dornellas, A.P.S., Santos, L.E., Ferreira, S.T., Galduróz, J.C. F., Wöhr, M., Schwarting, R.K.W., Andreatini, R., 2019. Mania-like elevated mood in rats: enhanced $50-\mathrm{kHz}$ ultrasonic vocalizations after sleep deprivation. Prog. NeuroPsychopharmacol. Biol. Psychiatry 88, 142-150. https://doi.org/10.1016/j. pnpbp.2018.07.002.

Wendler, E., de Souza, C.P., Vecchia, D.D., Kanazawa, L.K.S., de Almeida Soares Hocayen, P., Wöhr, M., Schwarting, R.K.W., Andreatini, R., 2016. Evaluation of 50$\mathrm{kHz}$ ultrasonic vocalizations in animal models of mania: ketamine and lisdexamfetamine-induced hyperlocomotion in rats. Eur. Neuropsychopharmacol. 26 (12), 1900-1908. https://doi.org/10.1016/j.euroneuro.2016.10.012.

Wintink, A.J., Brudzynski, S.M., 2001. The related roles of dopamine and glutamate in the initiation of $50-\mathrm{kHz}$ ultrasonic calls in adult rats. Pharmacol. Biochem. Behav. 70 (2-3), 317-323. https://doi.org/10.1016/s0091-3057(01)00615-3.

Wöhr, M., 2021. Measuring mania-like elevated mood through amphetamine-induced 50-kHz ultrasonic vocalizations in rats. Br. J. Pharmacol. https://doi.org/10.1111/ bph.15487 (in press)

Wöhr, M., Rippberger, H., Schwarting, R.K., van Gaalen, M.M., 2015. Critical involvement of 5-HT2C receptor function in amphetamine-induced $50-\mathrm{kHz}$ ultrasonic vocalizations in rats. Psychopharmacology (Berlin) 232 (10), 1817-1829. https://doi.org/10.1007/s00213-014-3814-9.

Wöhr, M., Schwarting, R.K., 2013. Affective communication in rodents: ultrasonic vocalizations as a tool for research on emotion and motivation. Cell Tissue Res. 354 (1), 81-97. https://doi.org/10.1007/s00441-013-1607-9.

Wright, J.M., Gourdon, J.C., Clarke, P.B., 2010. Identification of multiple call categories within the rich repertoire of adult rat $50-\mathrm{kHz}$ ultrasonic vocalizations: effects of amphetamine and social context. Psychopharmacology (Berl) 211 (1), 1-13. https:// doi.org/10.1007/s00213-010-1859-y.

Young, J.W., Henry, B.L., Geyer, M.A., 2011. Predictive animal models of mania: hits, misses and future directions. Br. J. Pharmacol. 164 (4), 1263-1284. https://doi.org/ 10.1111/j.1476-5381.2011.01318.x. 